International Journal of Linguistics, Literature and Culture
Available online at https://sloap.org/journals/index.php/ijllc/
Vol. 6, No. 2, March 2020, pages: 28-35
$\begin{aligned} & \text { ISSN: 2455-8028 } \\ & \text { https://doi.org/10.21744/ijllc.v6n2.866 }\end{aligned}$

\title{
Deconstruction of Minimalist Residential Design Development Practice in South Kuta
}

I Made Pande Artadi a A. A. Ngurah Anom Kumbara ${ }^{\text {b }}$ Putu Rumawan Salain ${ }^{c}$ Ida Bagus Gde Pujaastawa ${ }^{d}$

Article history:

Submitted: 09 December 2019

Revised: 18 January 2020

Accepted: 27 February 2020

\section{Keywords:}

capitalism;

design;

lifestyle;

minimalism,

residential;

\begin{abstract}
Minimalist residential develops was received massively in the middle of Balinese society, carrying the values of modernity by prioritizing function, the strength of ratio, and ignoring the past (ahistoric). The development and acceptance of these residences were contrary to Bali Provincial Regulation No. 05/2005 which requires residential buildings to display Balinese style. Massive acceptance of minimalist residential has implications in the dimensions of Balinese environmental, social, and cultural identity. The purpose of the study was to uncover the factors underlying the development and acceptance of minimalist dwelling in South Kuta. The research approach used was the cultural studies and design studies approach. The type of data collected was qualitative data obtained through observation, in-depth interviews, reading, and document checking. All data were analyzed using the qualitative interpretative analysis method. To understand and interpret the data, theories of deconstruction, consumerism, semiotics and identity theory are used. The results revealed that the development and acceptance of a minimalist residential design on a massive scale in South Kuta was due to the factor of capitalism and lifestyle changes.
\end{abstract}

International journal of linguistics, literature and culture (C) 2020. This is an open access article under the CC BY-NC-ND license (https://creativecommons.org/licenses/by-nc-nd/4.0/).

\section{Corresponding author:}

I Made Pande Artadi,

Doctoral Program Student, Cultural Studies Study Program, Udayana University, Denpasar, Indonesia.

Email address: m.artadi@yahoo.com

\footnotetext{
${ }^{a}$ Udayana University, Denpasar, Indonesia

${ }^{\mathrm{b}}$ Udayana University, Denpasar, Indonesia

${ }^{\mathrm{c}}$ Udayana University, Denpasar, Indonesia

${ }^{\mathrm{d}}$ Udayana University, Denpasar, Indonesia
} 


\section{Introduction}

Residential is a cultural product of the community that reflects its values, norms, and behavior. The form of dwelling is strongly influenced by the socio-cultural values of the inhabitants. This is confirmed by Soebroto (1983), stated that dwelling as a place for the process of socialization to take place, where an individual is introduced to various values, customs that apply in his community. So, the concept of a residential space is a mirror of the cultural values of the community concerned (Soebroto, 1983). Changes in values, patterns of behavior in society can result in a shift in the form of housing. Rapoport (1983), asserted that cultural changes affect the form of residential and the environment. The form of change does not take place spontaneously and comprehensively, but the point depends on the position of the elements of the house and its environment in the cultural system. This means that the Balinese form of dwelling can gradually change in values and behavior patterns of people are dragged into the current globalization.

Historically, the Balinese people are known as very strong communities that carry the values of tradition and maintain local culture. This fact is shown by the presence of various community movements that try to ward off and anticipate the negative effects of globalization, such as Baliseering (1020) and Ajeg Bali (2004). The concept of thinking and perspective of the movement proves that the Balinese are very firm in maintaining the integrity of their cultural heritage. The persistence of Balinese people towards tradition should also influence people's behavior in building dwellings. The reality that some have begun to abandon dwellings with traditional Balinese characters and are more interested in occupying minimalist images. The results of empirical research supported by the statement of Tino Wijaya as secretary of the Bali branch of the Indonesian Real Estate Entrepreneurs Association (REI) revealed that several major local Balinese developers (PT. Nuansa Bali Utama, PT. Sri Sedana and PT. Pratama Developer) played a role in developing the design minimalist residential area in the Subdistrict of South Kuta Badung.

Minimalist residential is a form of development of modern style in its most extreme form. Minimalism is a flow that carries functionality, rationality, universality and ignores the past (ahistoric). The expression of its physical form is dominated by geometric shapes, clean, simple, and without ornamentation. This means the development and acceptance of minimalist residential massively contradict Bali Province Regulation No. 05/2005 which requires buildings of Balinese architectural characteristics. The minimalist residential design looks contradictory with buildings of Balinese characters that were built and developed by local governments. Based on this background, this research will focus on the factors underlying the development and acceptance of the practice of developing minimalist residential design in South Kuta, Badung and the various implications it has.

\section{Materials and Methods}

The scientific approach used in research in cultural studies and design. These sciences are interdisciplinary so that they can involve various other branches of science. The study was conducted in Badung Regency with the location of the study as an analysis unit in the subdistrict of South Kuta. The reason for choosing this district is because most of the residential products from three major local developers in Bali (PT. Sri Sedana, PT. Bali Nuansa Utama and PT. Pratama Developer) are located in the area of South Kuta. Data collection methods used in research are field methods and library methods through observation techniques, in-depth interviews, reading and checking documents. All data were analyzed using the qualitative interpretative method by following the pattern of stages recommended by Huberman \& Miles (1986), namely: first, data reduction stage; second, the stage of display data presentation; third, the stage of drawing conclusions (Iskandar, 2009). To understand and interpret the data, the theory of deconstruction, consumerism, semiotics and identity theory are used.

\section{Results and Discussions}

To control the process of residential development, it continues to run in the corridor of the characteristics and local identity of Bali, the Bali Provincial Government issued Regional Regulation (Perda) No. 5/2005 concerning building architecture requirements. The presence of this Perda is also part of the government's efforts to meet the expectations of the locality and ethnicity movement that grows and develops in the midst of Balinese society (the 'steady Bali' movement) to control the development of global culture which is predicted to influence the existence and

Artadi, I. M. P., Kumbara, A. A. N. A., Salain, P. R., \& Pujaastawa, I. B. G. (2020). Deconstruction of minimalist residential design development practice in South Kuta. International Journal of Linguistics,

Literature and Culture, 6(2), 28-35. https://doi.org/10.21744/ijllc.v6n2.866 
sustainability of local culture. In Perda No. 5/2005, it is explained that the appearance of buildings must apply the norms of traditional Balinese development or pay attention to the forms and characteristics of traditional Balinese architecture or architectural forms that are distinctive in each district/city (Article 2, Perda No. 05/2005). The characteristics of Balinese traditional architecture referred to in this regulation are patterns of architectural appearance that can provide architectural images based on Balinese culture imbued with Hinduism. All can be achieved through the application of the principles of form which contain the identity and values of Balinese traditional architecture.

The principles of Balinese traditional architecture referred to regulation are layout, structure, materials, and ornamental principles that originate from the values of Balinese traditional residential philosophy and concepts. The philosophy and concept of Balinese traditional architecture in question is the philosophy of Tri Hita Karana, the concept of ulu-teben values, the concept of Triangga structure, the Cathuspata concept and the zone concept of Sangamandala. At the district level, particularly the Badung Regency has issued a derivative from the Regional Regulation, namely in the form of the Badung Regency Regulation No. 03/2016 concerning buildings. The aim is to adopt, elaborate on and make more detailed the substance of Perda No. 05/2005 in order to have special characteristics in accordance with regional potential so that it is easier to apply. The issue of Perda No. 05/2005 is expected to provide legal certainty to the process of controlling residential development in order to produce products that comply with the architectural principles of Balinese character.

Even, the reality that occurs is that minimalist residential development is growing more and more massive in the midst of the people of South Kuta. The growth in the number of minimalist houses which is increasingly high causes the face of residential. This region is to change into an urban environment with a visual form that tends to be rigid, industrial and foreign in local contexts. The image of Balinese dwellings that were previously unique and have an identity then eroded in the flow of modern waves with an urban atmosphere, and global image. The results revealed that there were certain determinants underlying the development and acceptance of minimalist residential design in South Kuta, namely: capitalism and lifestyle influences. These important aspects are spelled out more sharply in the following description:

a) Factors of capitalism

Marx stated that capitalism as an ideology is a means used by the dominant class or the ruling to distribute ideas. It can be accepted fairly by the whole society (Sanderson, 1993). In the industrial world, the practice of capitalism is clearly seen with all kinds of forms of production and reproduction to be made into commodities and marketed with the sole purpose of looking for profit. The power of production is not to explore the usevalue (utility value) but to find more value (profit) from the exchange rate. In this case, the objects of production are made as something has an exchange value. Ardono in William's article entitled problem in materialism and culture states that this capitalist attitude is stated to be a real form of 'false enlightenment' (Williams, 1980).

Enlightenment in its pure form was original 'liberation', in the sense of freeing humans from fear and building power (Adorno \& Horkhiemer, 1979). In fact, capitalism produces commodities for the needs of 'users', but the intended users have been rationalized in the economic system. In William's view, capitalism actually rejects the term 'user', but is more likely to use the term 'consumer'. The difference is the orientation of 'users' in buying products is for the fulfillment of essential life needs, while the 'consumer' hunts for the various product is for personal needs based on consideration of physical, psychological and sign values, namely: status, symbols, and prestige. This is what Adorno stated that capitalism as a form of 'mass deception' that creates 'needs' that are not needed essentially (Williams, 1980).

The economy run in the perspective of capitalism is not based on needs, but millions of want and desire, and libido flows without limits. Daniel Bell stated that in this condition of society, what is called society is actually not a group of people who have a common interest, but a combination of individual atoms looking for various forms of pleasure, satisfaction, and prosperity of each. The economic machine becomes an arena where each individual atom is tripping each other, cheating each other, nudging each other and preying on each other (Bell, 2011). This condition is stated by Michael Foucault as a condition of disturbance of mind and even madness. A condition in which humans are blinded to lustful desires, unable to control and tame desires (Foucault, 1989). Foucault's explanation can represent the desire of capitalism which always tries in any way to look for opportunities for the release of its energy for profit, including byways that break the law, oppose regulations, break morality and crush taboos. This means that the desire of capitalism can penetrate even dismantle every boundary of the value system, norms and even regulations that apply in society. 
In the case, this research the influence of capitalism is evident from the various efforts of developers in fulfilling the desire to make maximum profits through various means, namely violating and opposing the provisions of Bali Provincial Regulation No. 05/2005. Developers tend to override the principles of local architecture. Developer's compliance with regulations is only at the level of proposing building permits (IMB), then in the development process the developers deliberately set aside the principles of Balinese local dwelling, because they are considered to be in conflict with minimalist residential values. To smooth out these desires, developers often bribe local elements.

Local regulations as residential development regulations are enforced only in the licensing process so that the residential development project permit is issued by the government. Meanwhile, the style and image of the dwelling when built tend to follow the tastes and guidelines of the market, without considering prevailing regulations. The fact that occurs is almost most of the residential products have been built are minimalist by prioritizing physical shapes are geometric, formal, rigid, and far deviating from the principles of local Balinese architecture as stipulated in Perda No. 05/2005. The rise of residential development that deviates from the IMB standard provisions has been realized by the local government. The government as the enforcer of the regulation solah-if silent and allow this to happen. The reasons for building already built and humanitarian considerations are often justifications for the government not to enforce regulations. As a result, the same deviation is more often done by developers, minimalist residential development practices become increasingly massive.

The regional government as the executive body at the regional level should be a part that plays a role in implementing the applicable regulations, as enforcers of the regulations, even carrying out various executions of sanctions for violations that occur. The reality occurs is to obscure the regulation, deliberately allowing violations to occur, and to provide an opportunity for the distortion of the regulation's net for its own sake. This condition is stated by Jean Baudrillard in The Perfect Crime (1997) is a form of hyper-criminality namely crime goes beyond crime. Law enforcers commit acts of violation of the law, actions obscure the principles of regulation and even destroy traditional Balinese values. Aside from this, the practice of capitalism also utilizes loopholes in information technology advancement through social media advertising to manipulate actions in order to influence and attract consumer interest. Advances in virtual technology produce an illustration of residential product advertising goes beyond reality. Virtual technology in the design stage makes it easy for designers/architects to create artificial or superficial residential simulations with imaging engineering, which takes over the natural world of reality. Illustration of the advertisement of residential products belonging to the developer conjures up the natural conditions of Bukit Jimbaran in South Kuta which tend to be hot, dry and barren into cool, beautiful green residential areas. This is what Baudrillard stated as hyper-reality which is something goes beyond or beyond reality itself. The new reality exists transcends reality, in which all things present themselves as if they were something, even though it is not itself (Baudrillard, 1981).

The residential environment is present as a result of the sophistication of computer-simulated environment can be stated to be the world of 'simulakra' which is 'imitation of reality', wherein semiotics a marker is a simulacrum as something does not duplicate something else as a reference model, will but duplicates itself. Therefore the markers in this product illustration no longer have a natural relationship with reality, even completely cut off with reality. In semiotics, the signs build the image of dwelling in this illustration are stated to be false signs (pseudo sign), that is, the sign shown in the illustration of the dwelling environment is not genuine, artificial, even 'fake'. Markers build as if in fact (original), but fake. This reality by Baudrillard is said to be 'masks and perverts a basic reality' which is 'masking reality through signs' (Baudrillard, 1981). In this case, the practice of developing minimalist residential design in South Kuta is a form of capitalism that has led to the awareness of Balinese people in a condition where reality has been taken over by models or simulations of reality. The instincts of developer capacity appear by creating new realities, namely imaginary realities seem real. The hope is to be able to influence and foster consumer interest in buying these residential products.

b) Lifestyle influences

Stuart Ewen stated in the industrial world, style is an important part of the commodity creation process. A very important part of the style is how style becomes a commodity and enters the minds of people to be trusted (Sujana et al., 2019; Nyandra \& Suryasa, 2019). The inherent style in a commodity becomes the basis for consumers to have it, because it can be used as a medium to see, sort out, identify, equate, and at the same

Artadi, I. M. P., Kumbara, A. A. N. A., Salain, P. R., \& Pujaastawa, I. B. G. (2020). Deconstruction of minimalist residential design development practice in South Kuta. International Journal of Linguistics, Literature and Culture, 6(2), 28-35. https://doi.org/10.21744/ijllc.v6n2.866 
time differentiate themselves from others. In this case, the style can represent expressions of consumer tastes, identity, and identity. Contemporary society will distinguish itself with the status of others through their respective commodities, for example, is the social status in society will shine through the style of occupancy occupied. The whole pattern of actions distinguishes one person from another person or one group with another group is known as the 'lifestyle'.

Lifestyle can be used as a medium for socializing or interacting with others, as well as expressing themselves as part of a particular community. Suyanto stated lifestyle is adaptive, active, individual to social conditions in order to meet the need to unite and socialize with others (Suyanto, 2014). Adlin stated a person's lifestyle can be seen through the habits of how to dress, how to work, consumption patterns in response to stimulus from the process of involvement or interaction of a person in a social group (Adlin, 2006). In lifestyle, material culture has a very important position. Material culture becomes a part of contemporary human struggle when fighting over its social position (prestige) in people's lives. This statement is also emphasized by Bourdieu who emphasizes that material culture (artifacts) as an important factor in the struggle for social position, even the struggle for social position in social classes is largely determined by the relationships formed by these artifacts (Miller, 1987).

In the case, this research chose and decided to buy a minimalist residence was not merely driven by the need to have residential as a place of residence (denotative), that is only as a place to shelter from various problems came from external factors. Buying a minimalist residence is more driven by the desire to show social class or social position where he is. When a consumer chooses a minimalist occupancy, not just because they want to buy the essential function/first function/inherent function of the occupancy, but buying another social function. For Balinese people in South Kuta minimalist dwelling can be used as a medium to communicate lifestyle choices, namely a lifestyle of the expatriate group (descendants) or groups of foreigners living in Bali, in the form of 'modern' and 'upper class'.

Minimalist residential is acceptable in Balinese community has established a sign system, has a socially meaningful and meaningful nature, namely 'expatriates', 'westerns', 'modern' and 'upper class'. This means the meaning of the dwelling is formed is no longer meaningful single (denotative) as a place of residence or shelter, but gave birth to the second level meaning (connotative). Furthermore, the meaning of 'modern' and 'expatriate' (connotation meaning) is distorted as if the meaning of denotation is hunted and prioritized by consumers. This fact is in line with Rolan Barthes's statement the connotative meaning (in this case is 'modern' and 'expatriate') has been deformed and distorted, then the meaning is at the level of 'modern myth'. Meaning at the mythical level is the meaning of connotation as if it is considered a denotation or the meaning of connotation that plots denotation. Its function is to lead the community to the distortive meaning (Barathes, 1972). This means the acceptance of minimalist residential in the midst of Balinese society is due to the desire to consume denotative meanings which are present as a result of the deformation process of the second (connotative) meaning. The Balinese have consumed meaning at the level of modern myth.

The image that has been formed on a residential labeled 'minimalist' is then made into a very promising commodity by the developer. Through the 'minimalist' terms in residential products, it can encourage Balinese desires in South Kuta to buy and own the housing. All developers stated using the concept of minimalist dwelling on each product, developers are easier to attract the attention of consumers. Consumer behavior dwells on dreams, imagination, hallucination merely fulfills the desire to appear and be in the class structure of modern expatriate societies, encourages consumer behavior tends to be passive and uncritical to the occupancy purchased. The impact is the front view of the dwelling/outward form becomes the priority of the consumer in deciding/determining the dwelling to be purchased, without considering the function and standard of occupancy feasibility of each space within the dwelling. The stronger the minimalist image on the residential front view, the greater the chance to be chosen because it can represent the modern lifestyle expected by consumers.

Consumer behavior indicates consumers are entangled in the political ideology of the libidonomics of the developer. In this ideology, the developer uses a minimalist image as an instrument to persuade and arouse the passions or desires of consumers, so as to accelerate the process of purchasing a residence. According to Piliang, ideology of libidonomic movement with its main orientation is the distribution of stimulation, seduction, pleasure, excitement of passion or lust without limits (Piliang, 1998). In this case, it is not uncommon for consumers to forget for a moment about the essence of dwelling, get rid of the feasibility of lighting and air circulation in the dwelling, not caring about the meaning of a healthy living space is fit for 
habitation, because his mind has been contaminated by the urge to have minimalist dwelling which according to his perspective can bring him in the 'upper' style of 'modern expatriate' style.

In this case, consumers with Balinese cultural backgrounds no longer consider Balinese cultural values as the basis for choosing a housing. The Balinese dwelling design which previously put forward the philosophy and concept of an established space (the philosophy of Tri Hitakarana, Sanga Mandala, Triangga, Cathuspata, and Paduraksa) was subsequently gradually abandoned. The traditional values gave birth to the ulu-teben (upstream-downstream) space hierarchy and the arrangement of space groupings based on the main, intermediate and blistering zones are increasingly blurred. The implication is the creation of disorder and disorientation in the dimensions of Balinese residential values. The development and acceptance of minimalist dwelling in the midst of society create a disorderly or chaotic condition of the occupancy values of the community, even the pattern cannot be predicted (chaotic). In a further stage, there is an emptiness of norms (anomie) and even loss of norms and authentic values of Balinese occupancy.

The development and acceptance of minimalist residential in the midst of the people of South Kuta also has implications for depriving Balinese identity. Minimalist residential represents a global image that encourages and accelerates the process of cultural uniformity, especially in the field of housing. The practice of developing a minimalist residential design creates an environment that is homogeneous, anonymous, has no identity or no identity.

\section{Conclusion}

The determinants underlying the development and acceptance of minimalist residential design in South Kuta include two aspects, namely capitalism and lifestyle influences. The influence of capitalism can be seen from the efforts of developers in fulfilling desires by taking various methods, including violating and opposing the provisions of Bali Provincial Regulation No. 05/2005. This is done by building transactional relations, namely by giving money or certain facilities (gratuities) to local officials as facilitation so that all affairs and desires become smooth. The influence of capitalism is also evident from the behavior of developers who take advantage of advances in information technology in advertising and computer technology to take manipulative actions to attract consumer interest and hegemony.

The influence of lifestyle is the background of accepting minimalist residential in South Kuta represented through consumer behavior makes minimalist residence as a medium for building structures, constructing social identity and social positioning of the most ideal consumers in the Balinese society. Minimalist residential builds a 'modern' image is considered part of the 'upscale' lifestyle. The image has been formed is a very promising commodity for developers. All factors are then related through manipulative and imaging processes so as to spur the desire of contemporary Balinese people to buy and own the dwelling. In this case, consumers have been anesthetized by the practices of developer hegemony have colluded with the elements of the regional apparatus to manipulate the rules in order to smooth out various agency interests. Manipulative processes, imaging practices and changes in people's lifestyles encourage the development and massive acceptance of minimalist residential in the midst of Balinese society. The public as consumers have never been aware the presence of minimalist dwellings is part of the results of the practice of collusion and manipulative behavior seems to be honest, open ('fair') and in accordance with existing regulatory provisions.

\section{Conflict of interest statement}

The authors declared that they have no competing interest.

\section{Statement of authorship}

The authors have a responsibility for the conception and design of the study. The authors have approved the final article.

\section{Acknowledgments}

We are grateful to two anonymous reviewers for their valuable comments on the earlier version of this paper.

Artadi, I. M. P., Kumbara, A. A. N. A., Salain, P. R., \& Pujaastawa, I. B. G. (2020). Deconstruction of minimalist residential design development practice in South Kuta. International Journal of Linguistics,

Literature and Culture, 6(2), 28-35. https://doi.org/10.21744/ijllc.v6n2.866 


\section{References}

Adlin, A. (2006). Spiritualitas dan Realitas Kebudayaan Kontemporer. Forum Studi Kebudayaan FSRD-ITB.

Adorno, T., \& Horkheimer, M. (1979). Dialectic of Enlightenment, translated by J. Cumming.

Barthes, R. (1972). Mythologies. 1957. Trans. Annette Lavers. New York: Hill and Wang, 302-06.

Baudrillard, J. (1981). Simulations. New York: Semiotext (e).. 1988. Selected Writings.

Bell, D. (2011). The cultural contradictions of capitalism. The Hedgehog Review, 13(3), 65-72.

Ewan Stuart. (1998) Consumtion, Identity \& Style. Routledge

Foucault, M. (1989). Madness and Civilization: A History of Insanity in the Age of Wisdom.

Huberman, A. M., \& Miles, M. B. (1986). Concepts and methods in qualitative research: A reply to Donmoyer. Educational Researcher, 15(3), 25-26.

Iskandar, D., \& Pd, M. (2009). Metodologi Penelitian Pendidikan dan Sosial (Kuantitatif danKualitatif).

Miller, D. (1987). Material culture and mass consumption.

Nyandra, M., \& Suryasa, W. (2019). Lifestyle for stress buffer and reverse cell aging. International Journal of Health Sciences, 3(1), 17-23. https://doi.org/10.29332/ijhs.v3n1.276

Piliang, Y. A., Darwin, S., \& Ade, E. G. (2004). Dunia yang Berlari: mencari tuhan-tuhan digital. Gramedia Widiasarana Indonesia (Grasindo).

Rapoport, A. (1983). Development, culture change and supportive design. Habitat International, 7(5-6), $249-268$. https://doi.org/10.1016/0197-3975(83)90076-0

Sanderson, S. K. (1993). Sosiologi Makro. Sebuah Pendekatan terhadap Realitas Sosial,(Jakarta: Rajawali Press, 1993).

Soebroto, P.E. (1983). Aspek Aspek Sosial Phikologis pada Pemukiman Masyarakat berpenghasilan Rendah di kota kota besar. Makalah pada seminar Habitat Nasional. Ikatan Arsitek Indonesia (IAI) Edisi Maret 1983

Sujana, I. N., Mardika, I. M., \& Ujiyanti, N. M. P. (2019). Lifestyle of LGBT community in Pancasila legal country. International Research Journal of Management, IT and Social Sciences,6(1), 78-85. https://doi.org/10.21744/irjmis.v6n1.585

Suyanto, B. (2014). Sosiologi ekonomi: Kapitalisme dan konsumsi di era masyarakat post-modernisme. Prenada Media.

Williams, R. (1980). Literature and sociology. Problems in Materialism and Culture: Selected Essays. London: Verso, 11-30. 


\section{Biography of Authors}

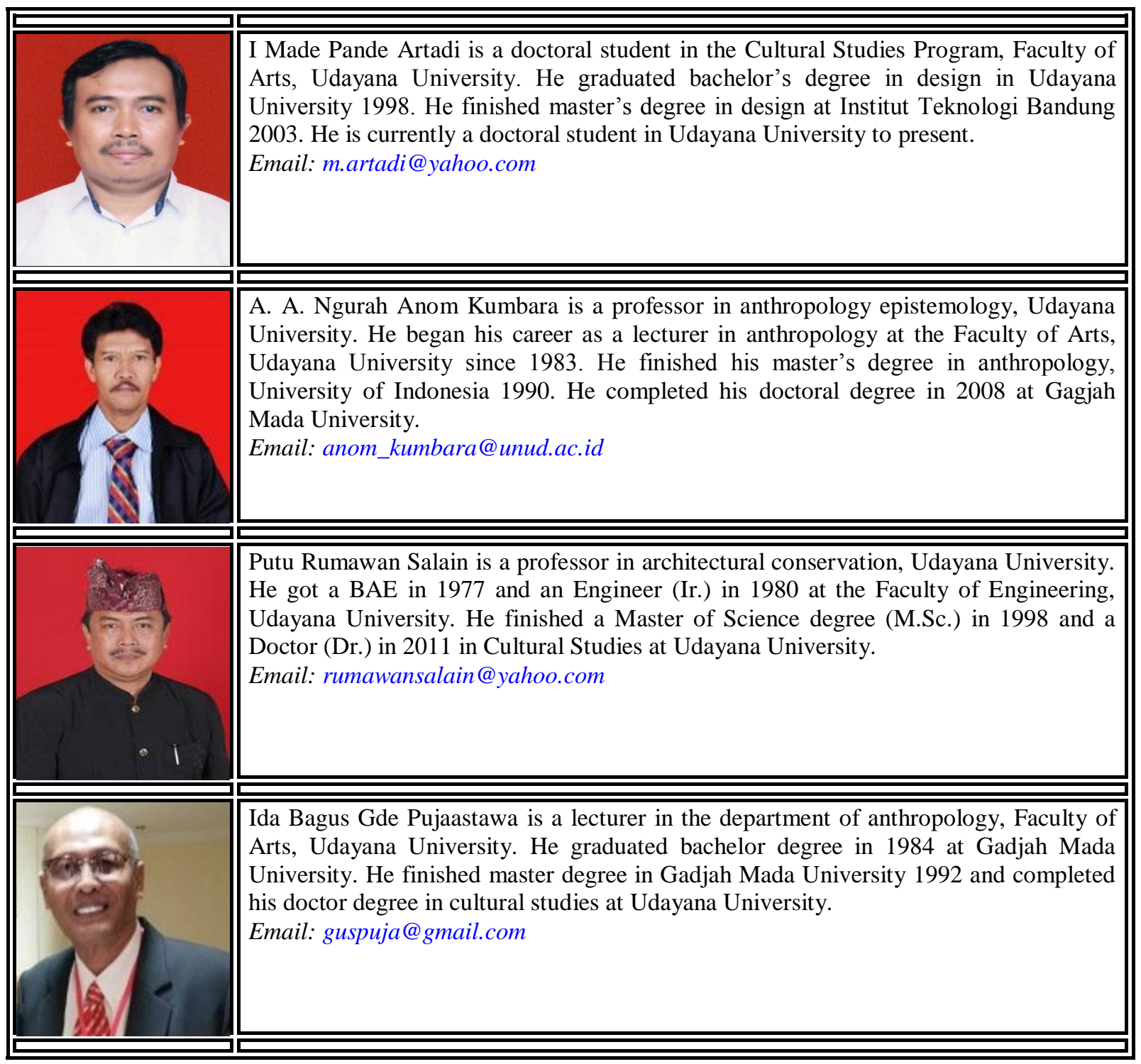

Artadi, I. M. P., Kumbara, A. A. N. A., Salain, P. R., \& Pujaastawa, I. B. G. (2020). Deconstruction of minimalist residential design development practice in South Kuta. International Journal of Linguistics, Literature and Culture, 6(2), 28-35. https://doi.org/10.21744/ijllc.v6n2.866 